\title{
The Contribution of Social Media, E-WOM On Brand Images and Purchase Intention
}

\author{
Arliyarini Erlikamila Yanti and Tatik Suryani \\ Department of Magister Management, STIE Perbanas Surabaya, Surabaya \\ e-mail: erlikamilayantiarli@gmail.com
}

\begin{abstract}
Recently, many companies used social media (Facebook and Instagram) for promoting their product and services. Is social media has a significant contribution on marketing performance? Many research focus on sales as marketing performance, less of the focus on other marketing performance such as: E-WOM, brand images and purchase intention. The specific focus of the research (1) to examine the influence of social media (Facebook and Instagram) toward EWOM, (2) to examine the influence of E-WOM towards brand image (3) to examine the influence of brand image toward purchase intention (4) to examine the influence of E-WOM toward purchase intention and (5) to examine is brand image mediating the influence of social media and E-WOM toward purchase intention. This research is qualitative design based on theoretical review and supported by many previous research. The basic concept of theory is about social media quality, EWOM, Brand Image, and Purchase Intention.The proposition as the result studies can be investigated empirically.
\end{abstract}

Keywords—Factor Analysis, EFA, Multiple Projects.

\section{INTRODUCTION}

$\mathrm{T}$ HIS time the community has realized the importance of increasing income and prosperity through doing business. This awareness grows new entrepreneurs both in services and goods. Business is done not only by professionals and adults, but there have been many business people from young people. So business can be done by anyone, both men and women, adults or even those who are still students, even business can be done by people who also work as employees as a side job which later can be made as the first choice when the business they are running can be more profitable than work in an agency or in a company.

In an effort to increase competitive advantage, SMEs also began to use a lot of technology in business. One form of technology that was widely applied was social media. From the perspective of consumers, social media began to be widely used in carrying out activities to meet needs, such as searching for information about an item or service and making transactions to purchase goods or services. Social media that are often used are Instagram and Facebook. Quoted from KATADATA, the number of social media users in 2019 increased by $20 \%$, reaching 150 million users, where the most Facebook users in the world beat Mexico, the Philippines, Vietnam and Thailand. In addition, Indonesia was also named as the 4 th country with the largest number of Instagram users defeating Turkey, Japan and the United Kingdom.

Considering the behavior of consumers who are starting to take advantage of a lot of social media both Instagram and Facebook, then SMEs as producers and providers of goods and services should take advantage of this opportunity to develop their businesses and businesses. SMEs can use social media to inform their whereabouts, information dissemination can be done through social media with promotion. SMEs can inform the company and its products to be known by consumers. In addition, social media can be used to establish intense relationships with customers.

Based on interviews with several SME business people, those who choose to carry out marketing activities through social media (Facebook and Instagram) because they think that marketing or promotion is easy, for example by using Facebook, sellers find it easier to interact with buyers, and emoticons provided by the Facebook application itself can represent a variety of reactions from potential buyers related to the goods they are marketed. Apart from that the seller can upload unlimited photos and make a separate album on his account specifically to make it easier for buyers to see the product being marketed. The seller can also express themselves by making a profile picture as attractive as possible as the identity of the business he made on his Facebook account, especially now that SMEs using social media have reached thousands, so it is important for SME owners to be as creative as possible to provide attractive traits for their businesses to be easily recognized by its regular customers or prospective buyers who will later become permanent customers.

The same SMEs can use other social media uses, namely Instagram, according to him Instagram is a social media that is present that has its own advantages that help him do business promotion. Similar to Facebook, Instagram is also a place for creative SMEs to stand out in public by having an attractive profile as their identity amid many other SMEs using Instagram. Sellers can post their products using captions or jargons that are deliberately made to be the hallmark of their products. With jargon written on caption and hashtag it can be a clue that makes it easier for other Instagram users to find it.

From the consumer side, the use of social media in meeting their needs has several considerations. According to the results of interviews I did with several social media users, as consumers they find it easier to get the items they need or want without having to move from their places or have to spend a lot of time. With the use of visual media socially, as consumers feel it is easy to make choices about the items needed or desired according to taste. If the seller has also given information about the price on the image of the product being marketed, then the consumer is also quicker to decide on a purchase or undo a purchase without having to make a bargain that is sometimes tough as if making an offline purchase or coming to the store directly. By using Facebook, 
The $1^{\text {st }}$ International Conference on Business and Engineering Management (IConBEM)

February $1^{\text {st }} 2020$, Institut Teknologi Sepuluh Nopember, Surabaya, Indonesia

consumers can easily get product visualizations contained in albums created by sellers on their account profiles.

The obstacle felt by consumers in using social media in meeting their needs is uncertainty about the quality of the goods they want. Apart from that in using social media, buyers sometimes do not get a quick response from sellers in interactions related to the process of finding information or transactions. Another thing that is felt to be an obstacle in transacting using social media is, the presence of the desired item that requires time, but is not a significant obstacle when the seller has provided certain information that can be agreed by the buyer.

The use of social media by SMEs in their marketing activities and the use of social media by consumers in decision-making builds several variables called Electronic Word Of Mouth (E-WOM), Brand Image, and Purchasing Decisions.

Intertwined communication on the use of Social Media in an intense and widespread, a means to obtain and share various kinds of information including product information of a brand. In previous studies E-Wom said as a positive or negative statement made by actual potential customers, or former customers about a company's product that is available to many people and institutions [6]. Conversations through Social Media around certain brand products conducted by users both between merchants and consumers or between consumers and other consumers that can occur widely are called E-Wom.

Brand image is an opinion or picture about a brand as a reflection of the association found in the memories of consumers. Opinions about a brand that are believed by consumers as the identity of the brand are adopted from a conversation or personal experience after the use of the brand's products. The more public knowledge of a product in a particular brand, the stronger the existing image of the brand. In the use of a product with a particular brand, consumers can provide an assessment of the benefits and product quality of the brand that will continue to be remembered in his memory. The memories that exist in consumers of a particular brand will be communicated to other consumers and continue to be done repeatedly consciously or will not build an opinion about the product. Good experience and information than a brand will give a good brand image, and vice versa if the experience shared by consumers and also the information obtained is bad, it will give a bad image of the product brand itself.

Kotler (2004) states that a Purchasing Decision is a problem solving process that consists of analyzing or identifying needs and desires, searching for information, researching sources of information on alternative purchasing, purchasing decisions, and post-purchase behavior. Purchase decisions can be said by the transaction shown by the customer after evaluating the goods and services [3].

The use of social media in marketing activities to build brand image on products from producers, both goods and service products. The relationship between Social Media (Instagram) and Brand Image has been proven in research conducted by Amalia Rizki and Edriana (2017) which states that exposure to Social Media (Instagram) has a direct and significant effect on Destination Imagery.

\section{THEORITICAL REVIEW}

\section{A. Media Sosial}

Social media is defined as the second generation of Web development and design, which aims to facilitate communication, secure information sharing, interoperability, and collaboration on the World Wide Web so that personal relationships are made easier. With its increasing use, this site is considered as a tool to create an online community of people with various interests, activities and goals. The internet has revolutionized communication, which allows individuals and organizations to overcome geographical and time constraints, which in turn allows consumers and companies to be connected around the world at any time. Kaplan and Haenlein in Srinivasan, Bajaj \& Bhanot (2016) describe social media as "a group of internet-based applications that are built on the ideological foundation and Web 2.0 technology, and which enable the creation and exchange of user-generated content. Social media is now used as a means for sell products, and this is very effective because it is able to bring together producers and consumers directly without any limitations on distance and time. Whenever consumers need a product, then that's when consumers can find information about these products.

In the study of Farzin \& Fattahi (2019) states that the Facebook user community shares their experiences in using a product brand on their Facebook account. In addition, now, consumers are easier to decide on a purchase by finding information through social networks and find out about references of the products they need through social media they have. Besides Facebook, the most popular social media used in online transactions that is quite popular is Instagram. Instagram is a social media application that allows users to share photos quickly that can be easily accessed by followers.

\section{B. Brand Image}

Brand image is an opinion or picture about a brand as a reflection of the association found in the memories of consumers. According to Aaker brand image is the impression of consumers about a brand. Brand image is defined all things related to the brand that is in the minds of consumers' memories. Tatik Suryani (2013). The concept brand image has attracted much attention from academics and practitioners because of its importance in influencing many marketing results.

Based on previous research, Brand Image is consumer perception of brand characteristics. How consumers keep opinions of a brand in their minds, which are believed to be facts and values of the brand. Can be in the form of a good rating or a bad rating in accordance with the experience of each experienced by consumers.

Brand image is constructed as an independent driver that influences consumers to make purchases, because brand image is an internal consideration in each consumer and motivates consumers in determining purchasing decisions.

According to Rangkuti (2013) Brand Image is a group of brand associations that are formed and attached to the minds of consumers. A brand is not just a name but a value, concept, characteristic, and image of a product. A good brand will create a superior brand image in the minds of consumers. 
The $1^{\text {st }}$ International Conference on Business and Engineering Management (IConBEM)

February $1^{\text {st }} 2020$, Institut Teknologi Sepuluh Nopember, Surabaya, Indonesia

\section{C. $E-W O M$}

In previous studies defining the word WOM as "verbal communication, person to person between recipients and communicators who are considered recipients as noncommercial, regarding the brand, product or service WOM can now be felt for everyone, because customer satisfaction is often shared through social media that has many people who can see each time someone posts on his account page. Patel (2015) has described WOM as "People trust people ... it's called word of mouth". That way, WOM can be interpreted that everyone will seek information from relatives and family who are believed to have used a product. That way, the stage of searching for information is much easier, because it has obtained references from people who are believed to have been able to reflect a product from a brand. The internet allows customers to share their opinions about, and experience with, goods and services with many other consumers; that is, to engage electronically by word of mouth. With the presence of social media, now everyone can express everything, from good experiences, to bad experiences in using a product. And today, it is called eWOM. EWOM is defined as " informal, person-to-person communication between perceived non-commercial communicators and recipients about a brand, a product, an organization, or a service".

\section{Purchase Intention}

In previous studies the purchase decision is that consumers consciously plan to make an effort to purchase a product. After going through a process in itself related to the fulfillment of its needs include identifying needs, searching for information (gathering information), evaluating, and determining which product choices will be purchased, the final stage is the purchase decision. Purchasing decisions can be considered as one of the main components of cognitive behavior that can show how someone intends to buy a particular brand or product. In addition, the purchase decision describes the transaction behavior displayed by the customer after evaluating the goods and services.

Purchasing decisions increase along with the price and promotion, brand recognition and also through increasing consumer awareness of the brand. Purchase decisions are consumer behavior in the form of intention, higher purchase intention means consumers have a higher purchase possibility.

The decision to purchase goods / services often involves two or more parties. Generally there are five roles involved according to Tatik Suryani (2016). The five roles include:

a. Initiator (initiator), the person who first suggested the idea of buying an item / service.

b. Influencers are people who have views or advice that influence purchasing decisions.

c. Decision maker (decider), namely the person who determines the purchase decision. The buyer (buyer), that is the person who makes a real purchase.

d. User (user), i.e. people who consume and use the goods / services purchased

According to Schiffman and Kanuk (2007: 16) decision making can be seen as a system consisting of inputs, processes, and outputs. The three stages in the decision making process, namely the stage of recognition of needs (consumers feel the needs), the search for information before buying and an assessment of alternatives. The process is influenced by the efforts of the company's marketing and socio-cultural environment and the psychological condition of consumers.

External factors that can be input and influence the decision-making process are efforts undertaken by marketers through marketing strategies and mix as well as external factors in the form of social, cultural and family environment, social class, informal and commercial sources, culture, subculture .

These external forces will influence the decision making process. This process begins with the introduction of needs by consumers. Followed by information search, evaluation of alternatives and buying decisions and evaluation after buying.

1. Recognize needs

At this stage consumers feel that there are things that are felt less and demand to be fulfilled. Consumers realize that there is a difference between what they experience and what is expected. Awareness of the need to meet these needs occurs because of stimulation from within and from outside. For example, thirst (from within), because of the smell of delicious bread in a food court in a shopping center.

\section{Looking for information}

What is the best that must be done to meet those needs, this question will appear to consumers. So that he can meet the needs in the best way, consumers try to find information. The search for this information will differ in degree, depending on the consumer's perception of the risk of the product to be purchased. Products that are considered to be risky will cause more complex decision making situations, so there will be more information seeking efforts. Conversely, products that are perceived as less risky will encourage consumers not to search too intensively for information.

3. Evaluate alternatives

Information obtained from several sources will be taken into consideration for consumers to make decisions. Consumers will consider the benefits including trustworthiness of the brand and the costs or risks that will be obtained when buying a product. Various risks such as time, energy, cost, psychological risk, social risk will be considered by consumers

\section{Make a decision}

After going through an evaluation with careful consideration, the consumer will make a decision. There are two factors that influence purchasing decisions and purchase goals, namely the attitudes of others, and situational factors that cannot be predicted (unexpected). The influence of other people's attitudes depends on the intensity of their negative attitudes towards alternative choices and the degree of motivation of consumers who will buy to follow others. While the unexpected situation is a situational factor that causes consumers to change their purchase goals and purchasing decisions. For example, financial conditions are suddenly not good. All these processes are inseparable from the psychological factors of the consumer and the consumer's experience of the product or service to be purchased.

5. Post-purchase evaluation

After buying, consumers will evaluate their decisions and actions in buying. If consumers assess the performance of products or services that feel the same or exceed what is expected, then the consumer will be satisfied and vice versa 
The $1^{\text {st }}$ International Conference on Business and Engineering Management (IConBEM)

February $1^{\text {st }} 2020$, Institut Teknologi Sepuluh Nopember, Surabaya, Indonesia

if the performance of the product or service received is less than expected, then the consumer will be dissatisfied.

Satisfaction and dissatisfaction experienced by consumers will affect subsequent behavior. If the consumer is satisfied, then he will show positive attitudes and behaviors towards the products and services he bought. He is likely to buy back, loyal or even do not hesitate to recommend to others to buy if asked. Conversely, if the consumer is disappointed, then he tends to be negative, stop the next purchase or tell unpleasant things about the product or service that he bought to other consumers. As a result this can adversely affect the promotion of the company.

\section{METHOD}

When viewed from the type of research, this research is included in a comparative causal study. Comparative causal study is a study used to investigate the possibility of a causal relationship based on observations of existing effects and look for factors that might be the cause through certain data.

When viewed from the type of data, this study is included in the type of research that uses primary data. Primary data is the source of data provided directly by respondents. In the research the primary data to be obtained is data regarding the credibility of ad stars, brand attitude, brand credibility and purchase intention, as explained by researchers through questionnaires.

When viewed from the type of research, this research is included in survey research. Survey research is gathering information about variables from groups of objects. In survey research, researchers want to find out the relationship between Social Media variables (Instagram and Facebook), E-Wom, Brand Image, and Purchasing Decisions as explained by researchers in a questionnaire aimed at Fashion SME consumers.

\section{Research Limitation}

The researcher determines the boundaries that will be expected so that this research is right on target and focused on its objectives. The limitation of this research lies in only consumers of fashion SMEs who have made purchases through Social Media and research locations that will only be conducted in the province of East Java. The sample in this study was limited to 150 consumers.

\section{Research Population}

Population is the sum of all objects (units or individuals) whose characteristics will be assumed. Population is a group of research elements, where the element is the smallest unit that is the source of the required data. The population in this study are all people of East Java who are SME Fashion consumers through Social Media.

\section{Research Samples and Sampling Techniques}

The sample is a portion of the population whose characteristics will be studied, and it is considered to be representative of the whole. The sample used in this study was a portion of the Surabaya community that became consumers of online fashion SMEs in Surabaya. The large sample, the researcher used the Slovin formula as follows:

$\mathrm{n}=\frac{N}{1+\left(N \cdot e^{2}\right)}$

Information:

$\mathrm{n}=$ sample size
$\mathrm{N}=$ population size

$\mathrm{e}=$ percent of leeway inaccuracy due to sampling errors that is still tolerated or desirable, in this sample is $10 \%$.

The total population gained from the entire city of Surabaya as much as $3,057,766$ people will get a sample of 100 people who will be the number of respondents who will be distributed later.

The sampling technique or sample selection is in the process of selecting a sample is to choose the sample that will be needed. In this step the researcher determines which elements will be sampled from the research conducted.

In this study, the technique used for sampling is nonprobability sampling. Non-probability sampling is a sampling technique where each member of the population does not have the same opportunity or opportunity as a sample. Indeed, with this kind of sample design, the problem of representation is not a problem. This study also uses non-probability convenience sampling is simple sampling, namely by taking only the units found. With convenience sampling, it will be easier for researchers to collect samples because the samples taken are based on existing units and not through representatives. With the following criteria:

1. Residing in East Java

2. Have an Instagram or Facebook account

3. Buy UKM Fashion products through Social Media

\section{RESEARCH INSTRUMENTS}

This study uses a questionnaire research instrument. Respondents answered about the response of Social Media, E-Wom and Brand Image to the Purchasing Decision and its impact on selected online SME customers in East Java and in the questionnaire already had answers in the form of questions followed by columns indicating the level from where the agreement agreed to the very disagree.

\section{A. Data and Data Collection Methods}

The following will be explained in relation to data and data collection techniques in the current study.

\section{B. Data}

In this study, the data obtained are primary data, primary data that is primary data is the source of data provided directly by data collectors. Data that directly examines objects and is obtained from distributing questionnaires distributed to research objects.

\section{Data Collection Technique}

Data collection is a systematic and standard procedure for obtaining the required data. This data collection method is used in research, namely by surveying through the distribution of questionnaires given to respondents to obtain primary data. Each questionnaire contains variables that are needed by researchers, then respondents are asked to fill out a questionnaire by answering some statements that have been provided by researchers. Data collection was carried out in all areas of Surabaya.

\section{Validity Test and Reliability Test}

The following will be explained related to the validity and reliability test criteria that have been determined in the current research. 
The $1^{\text {st }}$ International Conference on Business and Engineering Management (IConBEM)

February $1^{\text {st }} 2020$, Institut Teknologi Sepuluh Nopember, Surabaya, Indonesia

\section{E. Validity test}

Validity is used to measure the validity or validity of a questionnaire. A questionnaire will be valid if the respondent is able to answer all the questions that exist and will be proven through calculations with results that are able to meet the existing scale. If the measurement scale is invalid then it is not useful for the researcher because it does not measure or do what should be done. In this study, the validity test was carried out by measuring Convergent Validity that is with a measurement model with reflexive indicators assessed based on the correlation between item scores and construct scores calculated with PLS. This test was declared valid if, the correlation was significant (P-value $>0.7$ ).

\section{F. Reliability Test}

In addition to a questionnaire must be said to be valid, the questionnaire must also be declared reliable. Reliability shows the consistency and stability of a score (measurement scale). Reliability is an index that shows the extent to which a measuring device is reliable or reliable. reliability can also be used to measure the results of respondents and is also an indicator of a variable or construct. A questionnaire is said to be reliable or reliable if one's answer to a statement is consistent or stable over time.

The reliability measure is the Cronbach Alpha coefficient. If the Cronbach Alpha coefficient value in a research instrument can be said to be reliable if the reliability coefficient of the indicator produces a Composite Reliability value $>0.6-0.7$

\section{G. Data Analysis Technique}

In testing hypotheses, researchers use data analysis techniques Least Square (PLS) as a measurement tool.

\section{H. Descriptive Analysis}

Descriptive statistical analysis is used to provide a description or description of data that is seen from the value in the form of an average value (mean). This descriptive analysis also includes describing the results of the respondents chosen by the researchers. Especially respondents in accordance with the required sample, including the validity test and reliability test for the scale that will be used in this study.

\section{Statistic Analysis}

Statistical analysis is a measuring tool used by researchers to analyze data statistically. Researchers use the Partial Least Square (PLS) measurement tool because in this study has a mediating variable model, so that this research is more easily completed. In this study, researchers used an outer model (meansurement model) and inner model (structural model) as an evaluation model for testing.

\section{J. Stages of PLS-SEM Analysis}

In using the PLS-SEM analysis, at least five stages of the process must be carried out where each stage will affect the next stage, the following is the process of laying:

1. Model Conceptualization

2. Determine the Algorithm Analysis Method

3. Determine the Resempling Method

4. Draw a Path Diagram

5. Evaluate the Model

\section{Conceptual Analysis of PLS-SEM}

Conceptualization of the model is the first step that researchers must take if using PLS-SEM analysis with the WarpPLS 4.0 application. At this stage the researcher must conceptually define the construct being studied and determine its dimensionality for each of these constructs and the indicators for constructing latent constructs must determine whether they are formative, reflection or a combination of both ( $\mathrm{M}$ mode). then the direction of causality between constructs that indicate a hypothesized relationship whether it has a direct effect, indirect effect, spurious effect or moderate effect.

Determine the Algorithm Analysis Method Stages that must be done by researchers are algorithmic analysis methods. In PLS-SEM there are 2 algorithm settings, namely outer and inner which have the same function which is to calculate the latent variable score using a combination of linear and indicators. After determining the algorithm analysis method, the researcher moves to the next stage, which is determining the number of samples that must be met. For PLS-SEM does not require a large number of samples. However, the adequacy of the number of samples for PLS must also be considered, although PLS can be used for small samples.

\section{K. Determine the Resampling Method}

In general, there are two methods in resampling that researchers use in the PLS-SEM field, namely bootstrapping and jackknifing. The jackknifing method uses a subsample from the original sample grouped in grub for resampling. The results of the jackknifing method will be stable if the number of original samples is less than 100 and can be used on samples containing outliers. While the bootstrapping method uses all original samples for the resampling process. This method is often used in structural equation models. PLS only estimates the magnitude of the regression coefficient (beta) while the statistical significance value is interpreted by bootstrapping and jackknifing. PLS requires a large number of samples to get the normal distribution of the sample and then calculates the value of the Standard Error (SE). In addition to the two methods, the WarpPLS 4.0 program also added two new resampling methods, Stable and Parametric. The Stable method is the default resampling method in the WarpPLS 4.0 program. This option will calculate the P-value of the standard non-linear standard error for the empirical standard error generated by other available resampling methods. The Stable method is designed to produce a standard error with a small value that is relatively the same as a "fair" result (power $>0.8$ and a positive phase $<0.05$ ) for small samples and with non-normal conditions. While the Parametric method, P-value is calculated using multivariate normality assumptions. This option can be used for several tests in PLS that use data normality assumptions. The amount of resampling between these two methods is generally determined by the program itself (default 100), so researchers cannot set it (the default).

\section{Draw a Path Chart}

The next step is to draw a path diagram of the model to be estimated. In drawing a path diagram (path diagram), Falk and Miller (1992, p.18) recommend using the nomogram 


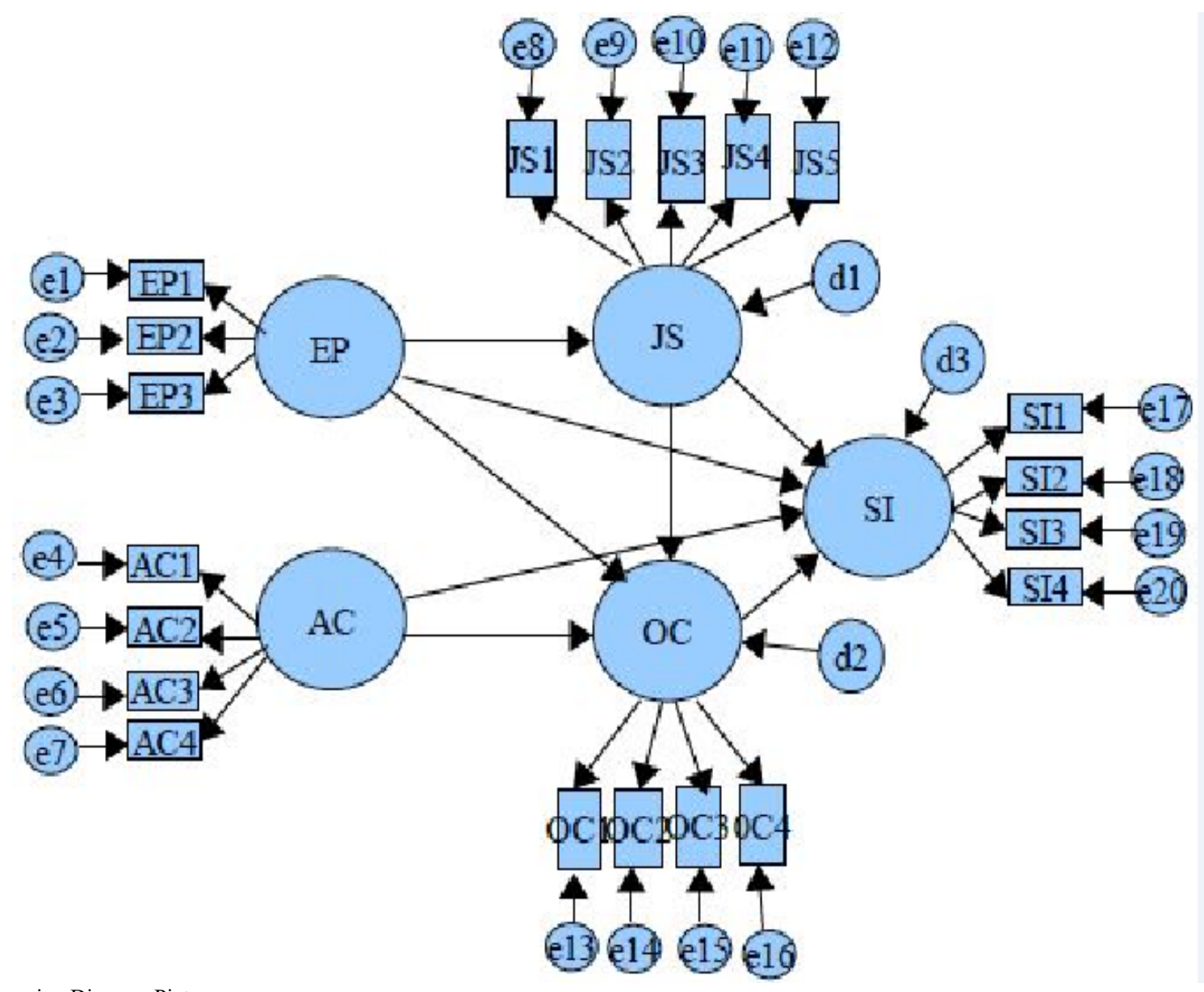

Figure 1. Drawing Diagram Picture

Sumber : http://www.statistikolahdata.com/2011/11/

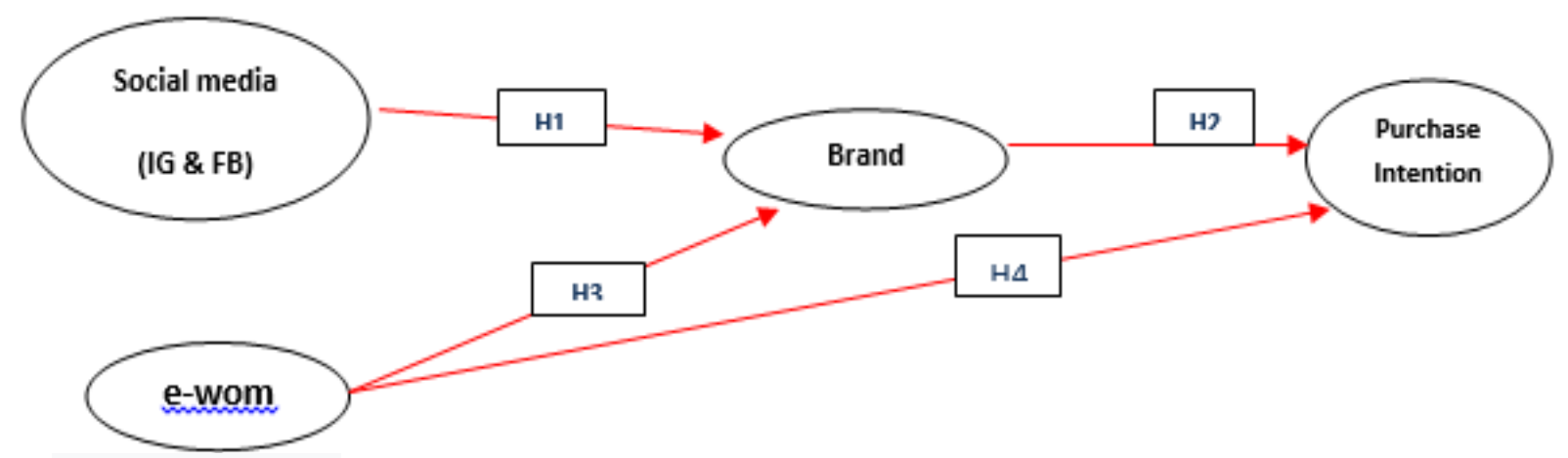

Figure 2. Framework of The Model.

reticular action modeling (RAM) procedure with the following conditions:

a. Theoretical constructs (Theoretical Constructions) which show latent variables must be drawn in the form of a circle or elliptical circle (circle).

b. Observed variables are indicators that must be drawn with squares.

c. Relationships or influences between variables or constructs are described in the direction of a single arrow.

Example of a path diagram can be seen in Figure 1.

PLS-SEM provides the added advantage of graphically drawing relationships between variables with a reticular action modeling (RAM) through the following four features: a. Ordering of theoretical constructs that is with PLS theoretical constructs or latent variables that are formed can be without the support of theory or prior knowledge.

b. Specifying of arrow that is with PLS direction indicator or observed variables can be made in the form of Mode A, mode B, or mode $\mathrm{M}$.

c. Specifyng of inner model that is with PLS associated with constructs or inner relations in the form of a causal chain system.

d. Blocking the manifest, theoretical variables and establishing their directions with PLS indicator blocks can be determined whether in the form of Mode A or Mode B with the principal component or canonical correlation. 
The $1^{\text {st }}$ International Conference on Business and Engineering Management (IConBEM)

February $1^{\text {st }} 2020$, Institut Teknologi Sepuluh Nopember, Surabaya, Indonesia

\section{Model Evaluation}

After drawing a path diagram, the model is ready to be estimated and evaluated as a whole. Evaluation of models in PLS-SEM using the WaspPLS 4.0 program can be done by assessing the outer model and inner model. Evaluation of measurement models or outer models can be done through confirmatory factor analysis (CFA) analysis by testing the validity and reliability of latent constructing items. Then proceed with the evaluation of structural models or inner models and significance testing to test the influence between constructs or variables.

After the PLS model has been estimated and evaluated, the final step that must be taken is to report and communicate the results of the analysis. In reporting the results of PLS analysis we can do a two-step approach, or also called a two-step approach. With a two-step approach we will start by reporting all the results from the outer model then proceed with the inner model.

\section{RESULT AND DISCUSION}

Based on the theoretical basis and the purpose of previous research and the problems that have been raised then as a basis for formulating a hypothesis can be presented in the framework of the model (see Figure 2).

\section{REFERENCES}

Suryani,Tatik (2008) Perilaku Konsumen di Era Internet Implikasinya pada Strategi Pemasaran.Graha Ilmu. Yogyakarta.
[2] Uttam Chakraborty, Savita Bath. (2017). "Credibility of Online Review and its Impact on Brand Image". Management Research Review. Vol. 41. No.1. Hal 148-164.

[3] Tariq Maryam, Abbas Tanveer, Abrar Muhammad, Iqbal Asif (2017). "EWOM and Brand Awareness impact on Consumer Purchase Intention : Mediating role of Brand Image”. Pakistan Administrative Review. Vol. 1. No. 1.

[4] Milad Farzin, Majid Fattahi. (2019) "EWOM through Social Networking sites and impact on Purchase Intention and Brand Image in Iran". Journal of Advances in Management Research. Vol. 15. No. 2. Hal. 161-183.

[5] Reham I. Elseidi, Dina El-Baz. (2016). "Electronic Word Of Mouth effects on Consumers' Brand Attitudes, Brand Image and Purchase Intention : an empirical study in Egypt. The Business Management Review, Vol. 7. No. 5.

[6] Ali Sahabi Yusuf, Ab Razak Che Hussin, Abdelsalam H. Busalim. (2018). "Influence of E-WOM engangement on Consumer Purchase Intention in Social Commerce". Journal Of Service Marketing. ISSN 0887-6045.

[7] Bagas Aji Pamungkas, Siti Zuhroh. (2016). "Pengaruh Promosi Di Media Sosial dan Word Of Mouth terhadap Keputusan Pembelian (Studi Kasus Pada Kedai Bontacos, Jombang)”. Komunikasi. Vol. X. No. 02. Hal. 145-160.

[8] Adamantios Diamantopoulos, Bodo Schlegemilch, Dayananda Palihawadana. (2018). "The relationship between country-oforigyn image and brand image as drivers of purchase intention: A test alternative perpectives". International Marketing Review. Vol. 28. No. 5. Hal. 508-524.

[9] Dokyun Lee, kartik Hosanagar, Harikesh S. Nair. (2014). "The Effect of Social Media Marketing Content on Consumer Engagement : Evidence from Facebook".

[10] Dr. R. Srinivasan, Prof. Resham Bajaj, Dr. Sandeep Bhanot(2016) "Impact of Social Media Marketing Strategis used by Micro Small and Medium Enterprise (MSMEs) on Customer acquisition and retention". IOSR Journal of Business and Management. e-ISSN 227-487, p-ISSn : 2319-7668. Vol. 18, Issue1. Ver.III. Hal. 91101 . 